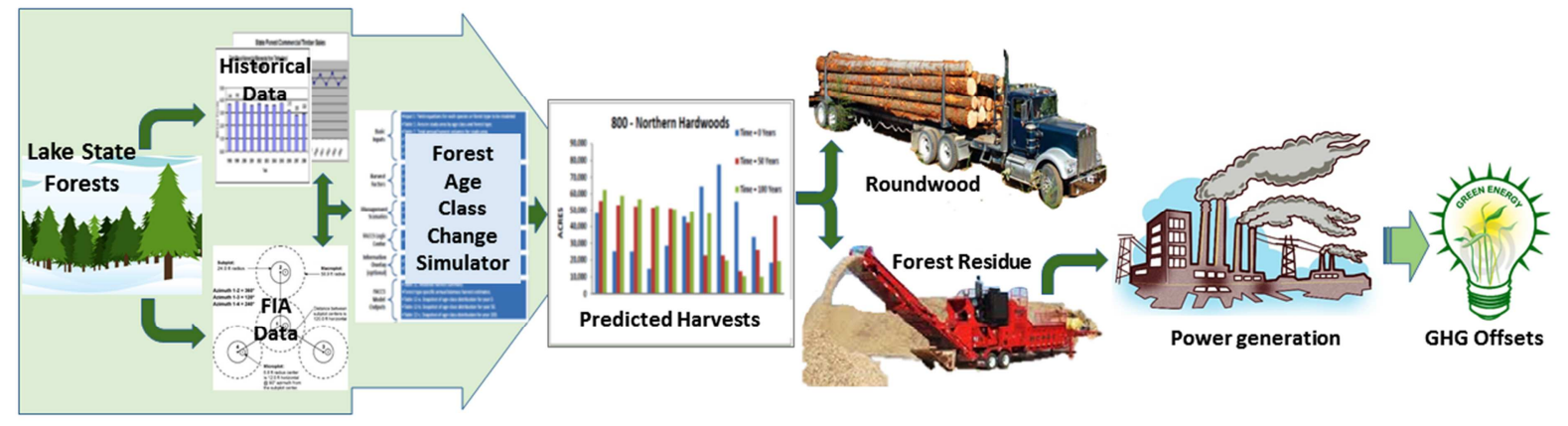




\title{
Assessing Sustainable Forest Biomass Potential and Bioenergy Implications for the Northern Lake States Region, USA
}

\author{
Sidhanand Kukrety ${ }^{\mathrm{a}}$, David C. Wilson ${ }^{\mathrm{b}}$, Anthony W. D' Amato ${ }^{\mathrm{c}}$, Dennis R. Becker ${ }^{\mathrm{d}}$
}

a. Corresponding author

Research Associate,

Department of Forest Resources,

University of Minnesota,

St. Paul - 55108

MN, USA

Phone: +1-612-625-6989

Email: sid.forester@gmail.com

b. Research Fellow,

Department of Forest Resources,

University of Minnesota,

St. Paul - 55108

MN, USA

c. Associate Professor,

Rubenstein School of Environment and Natural Resources,

University of Vermont,

Burlington - 05095

VT, USA

d. Associate Professor,

College of Natural Resources

University of Idaho,

Moscow - 83844

ID, USA 
Abstract:

Forestlands in the United States have tremendous potential for providing feedstocks necessary to meet emerging renewable energy standards. The Lake States region is one area recognized for its high potential of supplying forest-derived biomass; however, the long-term availability of roundwood harvests and associated residues from this region has not been fully explored. Better distribution and temporal availability estimates are needed to formulate emerging state policies regarding renewable energy development. We used a novel predictive methodology to quantify sustainable biomass availability and likely harvest levels over a 100-year period in the Lake States region. USDA Forest Inventory and Analysis estimates of timberland were combined with published growth and yield models, and historic harvest data using the Forest Age Class Change Simulator (FACCS) to generate availability estimates. Monte-Carlo simulation was used to develop probability distributions of biomass harvests and to incorporate the uncertainty of future harvest levels. Our results indicate that $11.27-15.71 \mathrm{Mt}^{-1} \mathrm{dry}$ roundwood could be sustainably harvested from the Lake States. Assuming 65\% collection rate, 1.87 $2.62 \mathrm{Mt} \mathrm{y}^{-1}$ residue could be removed, which if substituted for coal would generate $2.12-2.99 \mathrm{GW} \cdot \mathrm{h}$ of electricity on equivalent energy basis while reducing $\mathrm{GHG}\left(\mathrm{CO}_{2} \mathrm{e}\right)$ emission by $1.91-2.69 \mathrm{Mt}$ annually. In addition to promoting energy security and reducing GHG emissions, forest residues for energy may create additional revenues and employment opportunities in a region historically dependent on forestbased industries.

Keywords: Bioenergy; forest residue; GHG reduction; Lake States; sustainable harvest; biomass estimation. 
BRDA: Biomass Research and Development Act

ESDT: Exponential Smoothing with Damped Trend

60 ERFMax: Extended Rotation Forest Maximum Age

FACCS: Forest Age Class Change Simulator

62 FIA: Forest Service Forest Inventory and Analysis

63 GEIS: Generic Environmental Impact Statement

64 GHG: Greenhouse Gases

65 GMHT: Growth to Maximum Harvest Trend

66 HFRA: Healthy Forest Restoration Act

67 LTSY: Theoretical Long Term Sustained Yield

68 MSE: Mean Squared Error

69 MN-IHT: Minnesota Increasing Harvest Trend

70 MN-DHT: Minnesota Declining Harvest Trend

71 MN-HHT= Minnesota historical harvest trend (1980-2010)

72 
1. Introduction:

Ever increasing energy demands and scientific consensus on the risks associated with anthropogenically driven climate change [1] have stimulated global research into alternative energy resources. In the United States, fossil fuels contributed $88 \%$ of all electricity generated in 2012 with renewables accounting for the remainder [2]. Among fossil fuels, coal alone accounted for $43 \%$ of power generation, followed by natural gas (35\%). Wind energy contributed $28 \%$ of total renewable energy while the woody biomass derived energy contribution was $10 \%$ [3]. Contemporary bioenergy research gained momentum with promulgation of the Biomass Research and Development Act (BRDA) of 2000 [4], and accelerated further with enactment of the Healthy Forest Restoration Act (HFRA) of 2003 [5], Energy policy Act of 2005 [6], and over 350 state level incentives and regulations [7]. Despite the push in the field of bioenergy research, the market share contribution of woody biomass towards energy generation actually fell from $11 \%$ in 2002 to $7.5 \%$ in 2012 , largely due to expansion of natural gas production [2]. The absolute amount of wood energy production has remained relatively steady. At the same time, extracted biomass plus mortality $71 \%$ less than annual forest growth in most timberland areas [8 - 10]. Forestlands in the United States have been identified as holding tremendous potential for providing feedstocks necessary to meet emerging renewable energy goals. The updated Billion Ton study [8] indicated sustained availability of $291 \mathrm{Mt}$ y-1 of dry biomass forest biomass in the US based on current rates of forest harvesting, which are depressed due to the recent recession [8]. However, there are several areas of uncertainty regarding these and other estimates of feedstock availability $[11,12]$. First, landowner willingness and acceptance to harvest varies considerably within and across the public and private sectors indicating that the social availability of feedstocks will vary across different regions and ownerships [13 -15]. Second, not all forested areas are accessible and open to harvest, which effectively reduces the total market availability [16]. Additionally, areas set aside within working forest landscapes to preserve unique natural and cultural resources and sustain biodiversity restrict the area available for harvest. Moreover, biophysical constraints further reduce the sustainable biomass harvest. For instance, 
the Billion Ton study indicated that equipment recovery limitations reduced the estimated 67 Mt dry logging residue by $37 \%$, leaving only $41 \mathrm{Mt}$ available for wood energy application [8]. Third, the need to retain residues in the forest for soil conservation and to maintain nutrient cycling processes imposes a necessary constraint [e.g., 17 -19]. Fourth, since biomass feedstocks are less dense and have a lower heat value than fossil fuels, the economic and logistical constraints imposed by transportation infrastructure will also influence feedstock availability $[8,20]$. Lastly, the variation in delivered feedstock price will influence feedstock availability $[11,12,20]$. Collectively, these constraints must be rigorously incorporated into biomass availability estimates to inform policy development.

The northern Lake States region (encompassed by Minnesota (MN), Wisconsin (WI) and Michigan (MI)) is recognized as having a significant potential to supply forest-derived feedstocks [21] (Figure 1). Harvest residues are among the largest unused feedstock [20] with annual growth far exceeding removals. This presents an opportunity to increase harvest rates for strategic, economic, and forest health reasons [22]. In most cases, harvest residues are left on the forest floor while only a limited quantity is collected from the landing point for energy purposes [23]. The northern Lake States region also collectively represents an important confluence of supporting policies, third-party forest certification, and an emerging wood energy sector that in recent years has seen a surge in demand [24]. However, further increases are dependent upon the economic, environmental, and social feasibility of residue collection on one hand, and the proximity of bioenergy facilities to these forests on the other.

[Insert Figure 1. Ecological Province 212 of the northern Lake States, USA with major forest types depicted. Forest type classification is based on GAP data.]

\section{environmental sustainability, and quality of the forests to ensure sustainable production in the future. As} such, a thorough assessment of the environmental impacts and benefits of expanded bioenergy development is needed, which is critical for refining existing harvest guidelines and associated policies 
for protecting environmental quality. The long term projections of roundwood harvests and associated residues predicted by previous studies have neither been verified for correctness $[11,20,25,26]$, nor were the recorded harvests consistent. Better information about the distribution and temporal availability of forest feedstocks is needed to inform emerging state policies. Existing projections are fraught with uncertainties regarding future species composition and anticipated harvest levels.

Becker et al. [20] studied the existing and projected demand for residues in the Lake States region and concluded that total demand of 5.7 Mt dry residues exceeds the region-wide estimated and economically available 4.1 Mt [15]. There are other nation-wide studies that reflect the availability of timber and residue in the Lake States [8, 9]. In Minnesota, a Generic Environmental Impact Statement [25] evaluated the long term availability, and harvest of forest biomass under different harvest scenarios. Jakes and Smith [27] similarly predicted biomass availability in Michigan from 1980-2010. Despite these previous works, there is a lack of comprehensive studies in the region using contemporary techniques, such as simulation methods, to approximate the long term availability of biomass and associated uncertainties. Such assessments are a critical improvement over sustainable feedstock harvest estimates derived from average trends in past timber harvesting, like done for the Billion Ton update. The purpose of this study was to examine the environmental sustainability and capacity for wood energy production in the northern Lake States region. We assessed the long term (2010-2110) availability of biomass derived from roundwood and harvest residues and attempt to project harvest patterns based on past harvest trends for each state. The implications of residue utilization for energy generation and GHG reduction were also evaluated. Figure 2 shows the flow chart showing the sources and processes involved in the study.

[Insert Figure 2: Flow Chart showing the sources and process involved in the study]

2. Materials and methods:

2.1. Study area: 
In terms of geographical scope, this study is restricted to the Laurentian Mixed Forest Province (Province 212) [28] in northern MN, WI, and MI. There are approximately $210000 \mathrm{~km}^{2}$ of timberland in the three states. $77 \%$ of this timberland $\left(162000 \mathrm{~km}^{2}\right)$ falls within the study area. Although there is extensive forest cover in the region, long haul distances to major markets and slow adoption of scalable biomass energy technologies present significant bottlenecks in the development of regional wood energy systems and markets [9]. Standing roundwood and residue volumes within the study area are shown in Table 1. Forest Inventory and Analysis (FIA) data from the latest reporting period (2007-2011) indicate that Province 212 contributes $78 \%$ of the total growing stock in the three states, hence wherever required we extrapolated the results for the individual states as well. The focus of analysis in this study was restricted to four main ownership categories (Federal, State, County \& Local, and Private) that together occupy $77 \%$ of all the timberlands, and account for almost all the timber produced in this Province (Table 2).

[Insert Table 1. Dry merchantable roundwood and residue growing stock (Mt) .....Lake States.]

[Insert Table 2. Timberland area $\left(\mathrm{km}^{2}\right)$ in Province 212 by forest type....... also listed.]

\subsection{Forest Age Class Change Simulator:}

We estimated the potential availability of roundwood and harvest residues from the selected timberlands using FIA inventory data and age-class progression techniques combined with average stand growth and yield models. Growth and yield models were combined with FIA's timberland area estimates, and ageclass progression, harvesting, mortality and regeneration processes were added using the Forest Age Class Change Simulator (FACCS). Although, the EVALIDator tool [29] can provide estimates of existing forest biomass for different regions by ownership class, it is not designed to predict availability based on assumed harvest patterns over a period of time. Therefore, a modified version of FACCS [30] was used in which we identified past harvest trends, calculated timberland area and mortality rates for each forest type group and age-class, and parameterized the FACCS model to estimate sustainable harvest level by 
forest type group. FACCS is an area-control based model, wherein the area harvested annually is used to manage the development of the forest over time [30]. In FACCS, a unique change matrix for a specific forest type is linked to the FIA estimates of timberland area and yield by age-class. The area within each age-class moves as a function of time, harvest target, mortality, and a user-defined rotation length. Change matrices are linked to age-class specific yield models developed from recent FIA data to allow for estimation of biomass availability over time [31]. For more details on the FACCS refer to [30 - 33].

For this study two modifications were made to the base FACCS model. First, modifications were required in the local yield equations to account for differences in the average site quality between the three Lake States. Since in the base FACCS model, growth and yield were developed for a relatively small area located in northeastern MN [31], these yield models did not fully validate for WI and MI. To force validation, we adjusted the overall magnitude of the yield equations used in Domke et al. [31]. This was achieved by calculating an adjustment factor (i.e. a scalar coefficient used to adjust the yield equation) based on the proportionate difference between baseline standing volumes calculated from the initial yield equation and a corresponding FIA volume estimates for the areas of interest. The mathematical method used is related to the ratio-of-means calculations used in double-sampling of variables [34].

Secondly, to automate the identification of maximum sustainable harvest rates, and to allow implementation of non-declining yield conditions, it was necessary to develop an iterative harvesting methodology to generate values in the area change matrix based upon the initial area and projected timber volume removed. This modification was made by using Visual Basic programming within Microsoft Excel $^{\circledR}$. The new area change matrix generator works similarly to the base FACCS model, except for the changes in how harvesting is carried out. The new area change matrix generator repeatedly takes a small portion of the area from selected age-classes until the annual harvest goal is met. Age-classes above the extended rotation forest maximum age (i.e. certain forest types that are beyond their "normal rotation age" based on culmination of mean annual increment) (ERFMax) are harvested first, followed by a 
selection of up to 20 age-classes between rotation age and ERFMax containing the largest total area. In this study, the rotation age was based on the common commercial rotation age used for different forest types within each state. The harvesting simulation continues until either the harvest goal is met, or all selected age-classes have been harvested. If the harvest goal has still not been met, up to one-third of the area from the next oldest age-class below rotation age will be harvested to satisfy the harvest target. This process repeats until the harvest goal is met, or all age classes down to 20 years have been partially harvested. The condition in which harvests are pushed below the rotation age is monitored to identify the maximum sustainable harvest level using binary search methodology in an interval around the theoretical long term sustained yield (LTSY). This approach allows the user to determine if a given harvest goal is sustainable over a time period of interest. We used 120 years without forcing harvests below rotation age as our test of sustainability. The addition of an adaptive harvest algorithm was required for certain forest types containing severe age-distribution imbalances relative to expectations under a normal forest model. This adaptive harvest algorithm allowed for temporary departures from a level harvest to satisfy longterm harvest goals without forcing harvest below the rotation age at critical times in the process of bringing the forest back into age-distribution balance.

\subsection{Validation:}

For validation, the FACCS model predictions for total standing merchantable bole biomass (and separately for tops and limbs) were compared with EVALIDator outputs for the same product. We used the 95\% confidence intervals for the local yield equations identified in Domke et al. [31] as a guide to validate yield models for the areas of interest. We also used the $95 \%$ confidence intervals corresponding to FIA estimates for the same product to cross-reference our validation. In all, we considered the yield equations as validated if the FACCS and FIA estimates both fell within the 95\% confidence interval of the other prediction. The pre and post validation results along with adjustment factors used to adapt the yield models to growing conditions across the selected region are shown in Table 3. Greater adjustment 
factors were required to enable the application of local yield equations from $\mathrm{MN}$ to the more productive timberland of WI and MI.

[Insert Table 3. Comparison of total dry roundwood volume estimates (Mt) .... validation procedure.]

\subsection{Long Term Harvest Probabilities:}

To develop a useful range of future harvest probabilities, historical timber harvest data for the period between 1980-2010 were obtained from the USDA Forest Service for each state (Per. com.: Ronald J. Piva, Forester, Northern Research Station, St. Paul, MN). Initially, a next period forecast was created using Exponential Smoothing with Damped Trend (ESDT) [35]. The ESDT method has emerged as a preferred benchmark forecasting method in recent years [36]. The ESDT forecasting method uses smoothing parameters for both level (e.g. harvest level) and trend, combined with an additional damping parameter used to modify the influence of past trends. We selected these parameters such that the resulting set of forecasts minimized Mean Squared Error (MSE). While the ESDT forecast gives a good estimate of the expected future harvest barring any major economic changes, it does not sufficiently capture the likely variability in harvest levels over the 100 -year time period. The uninterrupted annual harvest data available for MN from 1980 - 2010 provides such a range of variability, encompassing a full economic "boom-bust" cycle in the timber sector. In contrast, the less continuous and less comprehensive data available for WI and MI did not identify a useful range of future harvests, pointing either towards flat growth (MI), or steeply declining harvests (WI); inconsistent with the large potential for sustainable harvest increases in both states. For these reasons, we used the MN harvest data as a proxy to develop a useful range of future harvests in WI and MI.

For each state, we used four different trendlines to bracket and quantify the likelihood of different future harvest scenarios. In order of decreasing harvest, these trends were; a) growth to maximum harvest trend (GMHT), b) MN increasing harvest trend (MN-IHT), c) exponential smoothing with damp trend (ESDT), and d) MN declining harvest trend (MN-DHT). The GMHT was defined as the maximum 
sustainable harvest level obtained from the FACCS run for each of the respective states. The MN-IHT trend has a slope identical to the regression trendline through the MN harvest data, but intersects the 2010 harvest level. Starting at 2010 levels, this line represents $0.54 \%$ growth per year. The ESDT with the lowest mean squared error with respect to the historic harvest data represents a flat scenario, continuing the next period forecast forward to 2110 . The MN-DHT represents the depressed scenario where the future harvests follow a declining trend. This trendline assumes a decline to 1980 harvest levels by 2110 , and represents a $0.18 \%$ decline per year. For the MN-IHT and ESDT scenarios, the average predicted harvest over the 100-year study period was taken as the most likely value whereas for the GMHT and MN-DHT scenarios the respective maximum and minimum values were used to develop upper and lower bounds for probability estimates in each state. Figure 3 shows the details of the trends developed for MN and extrapolated for WI and MI.

[Insert Figure 3. Graph showing different harvest trends developed from historical data for creating a probability distribution describing likely future harvests in Minnesota.]

To better describe the uncertainty inherent in our results, we used boundary analysis [37] and developed probability distribution curves of roundwood and residue availability for the portions of each state in the study region. The Generalized Uniform Trapezoidal distribution [38], which incorporates a maximum, minimum and two modes, was used to model the probability of mean harvest. We used the trapezoid package [39] embedded in R [40] for this purpose. Uncertainty was incorporated by using Monte-Carlo simulation (100,000 runs) of the trapezoidal distributions via the propagate package [41] in R. The parameters used for modeling roundwood and residue volumes are shown in Table 4.

[Insert Table 4. Annual dry roundwood and residue harvest estimates..... biomass availability]

2.5. Implications of Residue Use for Bioenergy: 
In this study, assuming $65 \%$ collection rate of residues ( $35 \%$ on-site retention), we explored use of residue in electric power generation and GHG reduction potential in the Lake States. We used $19 \mathrm{MJ} \mathrm{kg}^{-1}$ energy content (HHV) of wood, 36\% conversion efficiency, and 60\% power plant capacity [42 - 44] to assess the net power generation capacity. Additionally, avoided decay emissions from the forest floor and reduced emissions from the replacement of coal in power generation were also estimated. Following Olson [45], remaining biomass was calculated based on time and forest type specific decomposition constants. The decomposition constants compiled from other studies were used in this study as well [31]. The "remaining biomass" equation for each forest type was integrated over the 100-year time period to arrive at the total residuals remaining and decomposed. The general form of the definite integral used is:

$$
X(t)=\int_{0}^{100} x e^{-k t} d t
$$

Where $\mathrm{t}=$ time (years), $\mathrm{k}=$ decomposition constant, $\mathrm{x}=$ average annual residue production $(\mathrm{Mg})$, and $\mathrm{X}(\mathrm{t})=$ total remaining biomass. The GHG reduction potential of residues in electric power generation is essentially a combination of avoided decay emissions at the forest floor and reduced emissions at the power generation facility. Mann and Spath [46] argue that both these avoided emissions should be allowed as a credit against the emissions from electricity generation systems. Although there are studies on decomposition of wood in landfills [47, 48], long-term wood decay on the forest floor has not been widely studied. Depending on the distribution of residue on the forest floor, decomposition of wood may occur in varying proportions of aerobic and anaerobic decay. Since most forest residues come from tops and limbs having relatively more $(\approx 33 \%)$ lignin component as compared to the whole tree biomass [43, 47], the proportion of organic matter that finally decays is likely lower. We followed Mann and Spath [43] methodology and modeled the decay emissions assuming complete decomposition of $34.7 \%$ of the carbon in the residues under $50 \%$ aerobic conditions. Further, $10 \%$ of the methane emitted through litter decomposition was assumed to be oxidized by soil bacteria (methanotrophs) into $\mathrm{CO}_{2}$ [47]. Using this methodology, the emissions from decaying biomass were estimated on a $\mathrm{CO}_{2} \mathrm{e}$ mass basis as $2.99 \mathrm{~kg} \mathrm{~kg}-1$ 
of forest floor biomass. Since emissions for the exact biomass decay proportion (Aerobic vs. anaerobic) on the forest floor is unknown, we also estimated the GHG emissions for $100 \%$, and $90 \%$ aerobic decays used by Mann and Spath [43] for comparison. For GHG emission reduction potential we used reported average emissions for three coal-based electric power generation technologies [43] and calculated the net GHG reduction potential at the power plant by assuming replacement of coal with residues on equivalent power generation basis. The $\mathrm{GHG}\left(\mathrm{CO}_{2} \mathrm{e}\right)$ emissions associated with residues supply chain were calculated at $20.78 \mathrm{~kg} \mathrm{MW} \cdot \mathrm{h}^{-1}$ electricity produced (Kukrety S. 2015. (Unpublished work)).

\subsection{Assumptions:}

MN, WI, and MI each have different guidelines for post-harvest residue retention. MN guidelines require intentional minimum retention of $20 \%$ of fine woody debris along with an additional incidental breakage of $10-15 \%$ on site, totaling $35 \%$ minimum residue retention [17]. WI guidelines require retention of residue (<4inch diameter) from a minimum $10 \%$ of the harvested trees in addition to any fine woody debris that may have already been present on the site [18]. And MI guidelines mandate site specific retention of at least one sixth to one third of the harvested tree residues $(<4$ inch diameter) [19]. To maintain uniformity, we adopted $35 \%$ residue retention throughout the study region. Further, $10 \%$ of the area in each forest type was retained in age classes above the rotation age to maintain a minimum level of late-successional forest conditions to meet ecological objectives. The area of each forest type was assumed to remain constant throughout the modeled period. Other than background mortality calculated from the FIA data, no additional disturbance induced mortality was incorporated. The use of an integrated harvesting system that simultaneously procures both conventional timber products and logging residues was assumed given this is the primary way in which bioenergy feedstocks are procured in the region. Potential technological breakthroughs in harvesting and power generation cannot be predicted and are therefore not considered in future harvest scenarios.

3. Results and Discussion: 


\subsection{Roundwood harvest:}

Model results indicated a mean harvest of 11.27( \pm 0.89$) \mathrm{Mt}^{-1}$ dry roundwood timber across the study region with $95 \%$ confidence interval of $8.45( \pm 0.67) \mathrm{Mt}$ to $14.7( \pm 1.16) \mathrm{Mt} \mathrm{y}^{-1}$. Historical roundwood harvest data indicates that during the past three decades, on average this region produced $10.31 \mathrm{Mt}^{-1}$ of dry merchantable roundwood (MN: 2.98, WI: 3.39, and MI: 3.93). The maximum harvest $11.77 \mathrm{Mt}$ was recorded in 1994. Simulation results indicate that mean annual values are likely to remain lower than the 1994 level during the next 100-years. However, maximum sustained harvests of $15.71 \mathrm{Mt}^{-1}$ (MN: 4.26, WI: 4.82, and MI: 6.63) are possible. Given sufficient demand, the region has the potential to sustain substantially increase harvest levels.

The combined mean harvest from Province 212 extrapolated to all three states corresponds to 13.63 $\mathrm{Mt}^{-1}$, while the maximum (LTSY) is equivalent to $20.23 \mathrm{Mt}^{-1}$ of dry roundwood (MN: 5.15, WI: 6.79, and MI: 8.28). The projected probability distribution for dry roundwood harvests in MN is shown in Figure 3 and similar results were obtained for other states. Simulated harvest distributions for Province 212 are shown in Table 5.

[Insert Figure 4. Probability distribution results for Dry Roundwood (t), Minnesota 2011 2110]

[Insert Table 5 Simulation results showing predicted mean annual dry roundwood harvest... province 212]

Probability distributions for dry biomass harvests in northern MN indicate a mean availability of

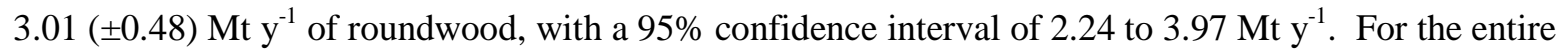
state this corresponds to $3.64 \mathrm{Mt} \mathrm{y}^{-1}$, which is close to the MN average harvest of $3.61 \mathrm{Mt}^{-1}$. This projection indicates no change in the roundwood harvest barring substantive technological or policy advances. The FACCS model projected a maximum sustainable dry roundwood yield of $4.26 \mathrm{Mt}^{-1}$ for 212 province of $\mathrm{MN}$ (5.15 $\mathrm{Mt}^{-1}$ for the State). This higher estimate of LTSY indicates that MN forests 
have the capacity to sustain substantially increased roundwood production should economic, social, and/or technological advances create the necessary demand.

Past harvest data indicate that dry industrial roundwood production in WI followed a trend similar to that observed in MN. The FACCS model projected a mean harvest of $3.52 \mathrm{Mt}^{-1}$ of dry roundwood with a $95 \%$ confidence interval of 2.66 to $4.52 \mathrm{Mt} \mathrm{y}^{-1}$. This corresponds to $5.47 \mathrm{Mt}^{-1}$ at the state level, and is more than the previous three decades' average harvest of $5.27 \mathrm{Mt}^{-1}$. This indicates a likelihood of slightly increased harvest rates during the next 100 years. The FACCS model generated LTSY of 4.82 $\mathrm{Mt}^{-1}$ (6.79 Mt $\mathrm{y}^{-1}$ for the state), indicating sufficient potential for increased roundwood harvest to satisfy increased demand for residual biomass for energy production.

In MI, the model projected a mean harvest of $4.75( \pm 0.73) \mathrm{Mt}^{-1}$ of dry roundwood with $95 \%$

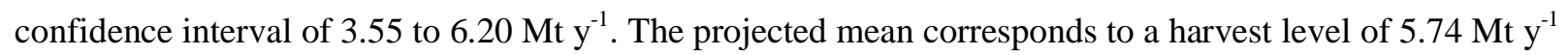
for the entire state. Examination of past harvest data indicates that industrial roundwood harvests in MI have been the most consistent among the three states, with the average harvest of $5.41 \mathrm{Mt}^{-1}$ during the past three decades. Projected harvest results indicate only a marginal increase in MI roundwood harvest over the time-frame considered. The FACCS model projected a maximum sustainable harvest of $6.63 \mathrm{Mt}$ $\mathrm{y}^{-1}$ from Province 212 in MI (8.28 Mt $\mathrm{y}^{-1}$ for the entire state) indicating that MI forests also have the potential to sustain substantially higher harvest levels.

\subsection{Residue availability:}

The details of harvest residue availability by ownership class are shown in Table 6. Our results indicate that roundwood harvests from the study area have the potential to generate $2.87( \pm 0.11) \mathrm{Mt}^{-1}$ of

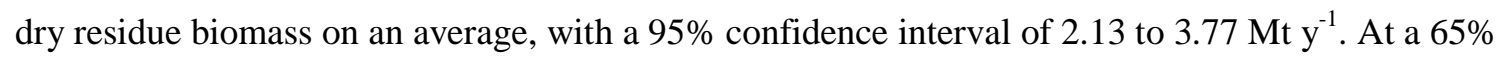
collection rate $\left(35 \%\right.$ on-site retention), this is equivalent to $1.87( \pm 0.07) \mathrm{Mt}^{-1}$ of dry harvest residues with a $95 \%$ confidence interval of $1.39( \pm 0.05)$ to $2.45( \pm 0.09) \mathrm{Mt}^{-1}$. Annual residue collection for $\mathrm{MN}$, WI, and MI, was estimated at $0.54( \pm 0.09) \mathrm{Mt}, 0.57( \pm 0.09) \mathrm{Mt}$, and $0.76( \pm 0.12) \mathrm{Mt}$, respectively. Assuming maximum sustainable harvest levels and a $65 \%$ collection rate, $2.62 \mathrm{Mt}^{-1}$ of dry residue can 
be collected from the study area (Table 6). These results can be extrapolated to a total potential residue harvest in the region of $3.54 \mathrm{Mt}^{-1}$ (MN: 1.03, WI: 1.08, MI: 1.44). The probability distribution of residue collection is shown in Figure 5.

[Insert Figure 5. Projected probability distribution for dry harvest residue production $(\mathrm{t})$ in Minnesota from 2011 - 2110]

[Insert Table 6. Annual availability of dry residues (Mt y-1) at 65\% collection rate in the Lake States under different ownership types and three harvest scenarios]

\subsection{Comparisons with other studies:}

Few other studies have examined regional availability of biomass feedstocks for comparison with our results, so we focused on comparing our state-level projections for MN with past work for this state (Table 7). Our projected average dry roundwood harvest of 3.01 Mt for MN was less than the average harvest of 3.70 Mt $\mathrm{y}^{-1}$ predicted by the 1994 GEIS study [25] for that 'Base scenario' but higher than the 'Baseline scenario' of $2.77 \mathrm{Mt} \mathrm{y}^{-1}$ predicted by Schwalm [26]. The GEIS study indicates projected harvest of 4.16 Million cords (4.48 MDT) at the state level. Similarly the FACCS projected maximum sustained yield of $4.26 \mathrm{Mt} \mathrm{y}^{-1}$ dry biomass was higher than the 'No even flow' projection of $3.76 \mathrm{Mt} \mathrm{y}^{-1}$ of Schwalm [26], but less than the GEIS [25] 'High scenario' predicting 5.42 $\mathrm{Mt} \mathrm{y}^{-1}$ harvest. The differences in projected harvest levels are likely due to different methodologies, and underlying assumptions followed by other studies. For instance, all the other studies assessed the availability of growing stock against fixed harvest projections based on the recent or most likely harvest target, whereas in this study harvest projections were based on harvest trends of past three decades normalized with incorporation of uncertainty using Monte-Carlo simulation. Additionally, this study used Exponential Smoothing with Damped Trend (ESDT) to arrive at the most likely next period harvest. Further, in this study $10 \%$ retention of late-successional forests was implemented to account for biodiversity conservation related objectives, which was not an assumption of the 1994 GEIS study, possibly resulting in marginally higher maximum sustainable harvest results in the GEIS. 
[Insert Table 7. Comparison of dry roundwood harvest projection results (Mt) for Province 212 region of Minnesota with other studies.]

For comparison, projections of residue collection from other studies in $\mathrm{MN}$ were converted to a $65 \%$ collection rate by using the proportion of statewide timberland in the study area. The projected results of this study were $12 \%$ more than the residue availability reported by Becker et al [12] and 15\% more than reported by Schwalm [26]. The Maximum dry residue availability scenario results were equal to Schwalm (5.5 million cord scenario) [26] but $13 \%$ more than the GEIS estimate (4.9 million cord scenario). In general, our projections for roundwood and residue production in $\mathrm{MN}$ were well matched with comparable studies for the region (Figure 6).

[Insert figure 6. Projected dry residue (Mt) availability in Province 212 of MN compared with results from other studies]

\subsection{Implications of Residue Use for Bioenergy:}

Assuming complete utilization of the $65 \%$ dry harvest residues collected from the minimum expected harvest, the northern Lake States have $1.46 \mathrm{GW} \cdot \mathrm{h} \mathrm{y}^{-1}$ electricity generating potential,. The maximum sustainable harvest (LTSY) level could contribute as much as $2.99 \mathrm{GW} \cdot \mathrm{h} \mathrm{y}^{-1}$. Under similar circumstances, the dry residues from average roundwood harvests in the region could generate $2.13 \mathrm{GW} \cdot \mathrm{h}$ $\mathrm{y}^{-1}$. Increased future demand for renewable energy derived from forest residues could increase total generation via increased roundwood chipping for energy, or through increased utilization of harvest residues. However, the availability of residues is largely constrained by timber harvesting associated with higher valued products, and retention guidelines in place for each state. Our results indicate that $86 \%$ of the $287 \mathrm{Mt}$ dry residues generated under the average harvest scenario in the northern Lake States would have completely decomposed during the 100-year study period. Assuming no removals, harvest residues would have generated decay emissions equivalent to 205 
rate, which avoids $65 \%$ of decay emissions at forest floor, an additional GHG reduction of 131.17 268.85 $\mathrm{Mt} \mathrm{CO}_{2} \mathrm{e}$ is possible assuming full replacement of coal in power generation on an equivalent electric power generation basis during the 100-year study period (Table 8). The net benefits however depend upon the conversion technology and type of coal replaced (e.g., bituminous, lignite), harvest and transportation emissions, and the type of wood decay on the forest floor. Similarly, utilization of residues for combined heat and power could be even more beneficial because of the substantially higher efficiency rates. The net GHG reduction potential of residues is summarized in Table 8.

[Insert Table 8. Power generation potential and net GHG reduction potential of forest derived residues ......study period]

\section{Conclusions:}

Researchers all over the world are trying to find methods to reduce the use of fossil fuels for generating electricity and heat by substituting with biomass. However, regional, and policy-relevant estimates of sustainably available biomass are sorely lacking, limiting the opportunity to maximize benefits. In this study an attempt was made to assess future roundwood harvests in the northern region of MN, WI, and MI under scenarios of different harvest likelihoods over a period of 100-years. The implications of collecting residues for energy generation and associated GHG reduction benefits was also evaluated. Our results indicate that the study region has the potential to supply 11.27 - 15.71 Mt dry roundwood annually on sustainable basis. Assuming 65\% collection, 1.87 - 2.62 Mt of dry residue produced from these harvests could generate $2.13-2.99 \mathrm{GW} \cdot \mathrm{h} \mathrm{y}^{-1}$ of power. The substitution of forest residues for coal on equivalent power generation basis has potential to reduce GHG emissions by $1.91-2.69 \mathrm{Mt}_{\mathrm{CO}_{2} \mathrm{e}}$ annually. In addition to promoting energy security and reducing GHG emissions, the use of forest residues for energy would create additional income and employment opportunities in the forest-based sector.

\section{Acknowledgements:}


463 This project was supported by the USDA/DOE Biomass Research and Development Initiative (\#2009-

464 10006-05948). Initial support provided by Grant Domke in providing understanding of the FACCS model

465 is greatly appreciated. The authors also wish to thank Ronald J. Piva (FIA), Anna Dirkswager (Minnesota

466 DNR) for data support and other members of the project team for their valuable suggestions during the course of this study. We also thank the editor and the anonymous reviewer for their valuable suggestions. 


\section{References:}

[1] IPCC. Summary for Policymakers. In: Stocker TF, Qin D. Plattner GK, Tignor M, Allen SK, Boschung JA et al., editors. Climate Change: The Physical Science Basis. Contribution of Working Group I to the Fifth Assessment Report of the Intergovernmental Panel on Climate Change. 2013. Cambridge University Press, Cambridge, United Kingdom and New York, NY, USA.

[2] EIA. Summary Statistics for the United States 2003-2013. Net Generation (From Tables 3.1.A. and 3.1.B.) Available at http://www.eia.gov/electricity/annual/html/epa 01 02.html Data updated annually. (Accessed 12.05.2015)

[3] EIA 2012, State energy profiles (Accessed December 12, 2013) http://www.eia.gov/state/state-energy-profiles.cfm?sid=MN; http://www.eia.gov/state/state-energy-profiles-analysis.cfm?sid=MI ; http://www.eia.gov/state/state-energy-profiles-analysis.cfm?sid=WI

[4] BRDA. Biomass Research and Development Act of 2000. Available at: http://www.biomassboard.gov/pdfs/biomass_rd_act_2000.pdf (Accessed 15.05.2015)

[5] HFRA. Healthy Forest Restoration Act of 2003. Available at: http://www.gpo.gov/fdsys/pkg/BILLS-108hr1904enr/pdf/BILLS-108hr1904enr.pdf (Accessed 15.05.2015)

[6] EPA. Energy policy Act of 2005. Available at: http://energy.gov/sites/prod/files/2013/10/f3/epact_2005.pdf (Accessed 15.05.2015)

[7] Becker DR, Moseley C, Lee C. A supply chain analysis framework for assessing state-level forest biomass utilization policies in the United States. Biomass Bioenerg 2011; 35(4):1429-39.

[8] Perlack RD, Stokes BJ, Lead Authors. US Billion-Ton Update: Biomass Supply for a Bioenergy and Bioproducts Industry. Oak Ridge (TN); Oak Ridge National Laboratory. 2011 August. 227 p. ORNL/TM-2011/224. Prepared for the USDOE under contract DE-AC05-00OR22725.

[9] Smith WB, Miles PD, Perry CH, Pugh SA, Coordinators. Forest Resources of the United States. Washington DC.: U.S. Department of Agriculture, Forest Service; 2007 March 336 p. Gen. Tech. Rep. WO-78.

[10] Demchik MC, Abbas D, Current D, Arnosti D, Theimer M, Johnson P. Combining Biomass Harvest and Forest Fuel Reduction in the Superior National Forest. Minnesota J Forest 2009;107(5): 235-41.

[11] Gan J, Smith CT. Availability of logging residues and potential for electricity production and carbon displacement in the USA. Biomass Bioenerg 2006;30(12): 1011-20.

[12] Galik CS, Abt RC, Wu Y. Forest Biomass Supply in the Southeastern United States Implications for Industrial Roundwood and Bioenergy Production. J Forest 2009;107(2): 69-7.

[13] Munsell JF, Germain RH. Woody biomass energy: an opportunity for silviculture on nonindustrial private forestlands in New York. J Forest 2007;105(8): 398-02.

[14] Aguilar F, Garrett HE. Perspectives of Woody Biomass for Energy: Survey of State Foresters, State Energy Biomass Contacts, and National Council of Forestry Association Executives. J Forest 2009;107(6): 297-06.

[15] Becker DR, Eryilmaz D, Klapperich JJ, Kilgore MA. Social availability of residual woody biomass from non-industrial private woodlands in Minnesota and Wisconsin. Biomass Bioenerg 2013 September; 56:82-1.

[16] Butler BJ, Ma Z, Kittredge DB, Catanzaro PF. Social versus biophysical availability of wood in the northern United States. North J Appl For 2010;27(4):151-9.

[17] MNFRC. Minnesota Forest Resources Council. Sustaining Minnesota Forest Resources: Voluntary Site-Level Forest Management Guidelines for Landowners, Loggers and Resource Managers. Minnesota Forest Resources Council, St. Paul, Minnesota. 2005. 55 p. Available at: http://www.frc.state.mn.us/documents/council/site-level/MFRC_FMG\&Biomass_2007-12-17.pdf (Accessed 09.03.2012) 
[18] WIDNR. Wisconsin department of Natural Resources, Wisconsin's Forestland Woody Biomass Harvesting Guidelines. 2008. Available at:

[19] MIDNR. Michigan Department of Natural Resources and Environment. Michigan Woody Biomass Harvesting Guidance. 2010. Available at: www.michigan.gov/dnre (Accessed August 09.08.2013).

[20] Becker DR, Skog K, Hellman A, Halvorsen KE, Mace T. An outlook for sustainable forest bioenergy production in the Lake States, Energ Policy 2009;37(12): 5687-93.

[21] BRDI: Biomass Research and Development Initiative - Increasing feedstock production for biofuels: economic drivers, environmental implications, and the role of research. United States Department of Energy and United States Department of Agriculture 2009; 167 p. Report. Available at: http://www.esd.ornl.gov/eess/8_Increasing_Biofuels_Feedstock_Production.pdf (Accessed 09.08.2013).

[22] Sundstrom S, Nielsen-Pincus M., Moseley C, McCaffery S. Woody Biomass Use Trends, Barriers, and Strategies: Perspectives of US Forest Service Managers. J Forest 2012;110(1):16-4.

[23] D'Amato AW, Bolton NW, Blinn CR, Ek AR. Current status and long-term trends of silvicultural practices in Minnesota: a 2008 assessment. St Paul, Minnesota. December, 2009. 58 p. Available at: http://mn.gov/frc/documents/council/UMN_silvics_Staffpaper205_2008report.pdf University of Minnesota, Department of Forest Resources. Staff Paper Series No.205. (Accessed12.12.2013)

[24] Becker DR, McCaffrey S, Abbas D, Halvorsen KE, Jakes P, Moseley C. The conventional wisdoms of woody biomass utilization. J Forest 2011;109(4):208-18.

[25] GEIS. Final Generic Environmental Impact Statement on Timber Harvesting and Forest Management in Minnesota. Tarrytown, NY. April, 1994, 549 p. Available at: http://hdl.handle.net/11299/169527. Prepared for the Minnesota Environmental Quality Board by Jaakko Pöyry Consulting, Inc. (Accessed 09.03, 2012)

[26] Schwalm CR. Forest harvest levels in Minnesota: Effects of selected forest management practices on sustained timber yields. St. Paul, MN. 2009. 40 p. Available at https://conservancy.umn.edu/bitstream/handle/11299/107772/204.pdf?sequence=1 Tech. report. University of Minnesota, Department of Forest Resources. Staff Paper Series No. 204 (Accessed 19.12.2013)

[27] Jakes PJ, Smith WB. Michigan's predicted Timber Yields 1981-2010. St. Paul, MN. 1983, 98 p. Available at: http://www.nrs.fs.fed.us/pubs/rp/rp nc243.pdf? U.S. Department of Agriculture, Forest Service, North Central Forest Experiment Station. Res. Pap. NC-243. (Accessed 09.03.2013)

[28] Bailey RG. Description of the ecoregions of the United States, 1995. 77 p. Available at: http://www.fs.fed.us/land/ecosysmgmt/Rocky Mountain Research Station, Fort Collins, Colorado. USA. Miscellaneous Publication No. 1391. (Accessed12.12.2013)

[29] FIA. Forest Inventory and Analysis. EVALIDator Version 1.5.1.04. Available at: http://www.fia.fs.fed.us/tools-data/default.asp (Accessed 12.12. 2012)

[30] Domke GM, Ek AR. Model development for rapid estimation of woody biomass availability. Orlando, FL: Society of American Foresters National Convention; September 30, 2009.

[31] Domke GM, Becker DR, D' Amato AW, Ek AR, Woodall CW. Carbon emissions associated with the procurement and utilization of forest harvest residues for energy, northern Minnesota, USA. Biomass Bioenerg. 2012;36 December: 141-50.

[32] Domke GM. Resource assessment and analysis of aspen dominated ecosystems in the Lake States. (Ph.D. dissertation). St Paul: University of Minnesota; 2010.

[33] Wilson DC, Domke GM, Ek AR. Forest Age Class Change Simulator (FACCS): A spreadsheet based model for estimation of forest change and biomass availability, St Paul, Minnesota. 2014. 21 p. Available at: http://www.forestry.umn.edu/prod/groups/cfans/@pub/@cfans/@ forestry/documents/asset/cfans_ 
asset_473421.pdf Tech. report. University of Minnesota, Department of Forest Resources. Staff Paper Series No. 228 (Accessed 19.12.2013).

[34] Avery TE, Burkhart HE. Forest Measurements. $5^{\text {th }}$ Edition. McGraw Hill. New York, NY. 2002. $331 \mathrm{p}$.

[35] Gardner ES Jr, McKenzie E. Forecasting trends in time series, Manage Sci 1985; 31 October: 1237-46.

[36] Fildes R, Nikolopous K, Crone S, Syntetos A. Forecasting and operational research: a review. J Opl Res Soc. 2008 May;59: 1150-72.

[37] Johnson DR, Willis HH, Curtright AE, Samaras C, Skone T. Incorporating Uncertainty Analysis into Life Cycle Estimates of Greenhouse Gas Emissions from Biomass Production. Biomass Bioenerg 2011;35(7): 2619-26.

[38] Van Dorp JR, Cruz S, García J, Herrerías R. An Elicitation Procedure for the Generalized Trapezoidal Distribution with a Uniform Central Stage, Decision Anal 2007;4(3): 156-66.

[39] Hetzel JT. Trapezoid: The Trapezoidal Distribution. 2012. Available at: http://cran.rproject.org/web/packages/trapezoid/index.html (Accessed 21.12.2013).

[40] R Development Core Team. R: A language and environment for statistical computing. $R$ Foundation for Statistical Computing, Vienna, Austria. 2008. Available at: http://www.Rproject.org.

[41] Spiess AN. Package 'propagate'. 2013. Available at http://cran.rproject.org/web/packages/propagate/index.html (Accessed 21.03.2013)

[42] Mann MK, Spath PL. Life Cycle Assessment of Biomass Gassification Combined-Cycle System: National Renewable Energy Laboratory, Golden, Colorado 1997. 160 p. Tech. Report. NREL/TP430-23076.

[43] Mann MK, Spath PL. A life cycle assessment of biomass cofiring in a coal-fired power plant. Clean Prod Processes 2001;3(2): 81-91.

[44] EIA. Monthly capacity factors for select renewable fuels and technologies. January 2011October 2013. Updated on January 15, 2014. Available at http://www.eia.gov/todayinenergy/detail.cfm?id=14611 (accessed May 12, 2015)

[45] Olson JS. Energy Storage and the Balance of Producers and Decomposers in Ecological Systems. Ecology 1963;44 (2): 322-31.

[46] Mann MK, Spath PL. Life Cycle Assessment Comparison of Electricity from Biomass, Coal, and Natural Gas. (Unpublished Presentation) National Renewable Energy Laboratory, Golden, Colorado. 2002. Available at: http://www.dep.state.fl.us/Air/emission/bioenergy/tallahassee/appendix_a.pdf (Accessed 09.12.2012)

[47] Barlaz MA. Carbon storage during biodegradation of municipal solid waste components in laboratory scale landfills. Global Biogeochem Cy 1998; 12(2): 373-80.

[48] Michaels JA, Skog KE. The decomposition of forest products in landfills. Int Biodet Biodeg 1997;39(2-3):145-58. 
Table 1. Dry merchantable roundwood and residue growing stock (Mt) on timberland across different ownership classes in 212 Ecoregion of the northern Lake States.

\begin{tabular}{lcccrc}
\hline \multicolumn{7}{c}{ Roundwood $^{\text {State }}$} & National $^{\mathbf{1}}$ & State & & \\
\hline Michigan & 75.75 & 75.92 & 5.52 & 236.44 & 393.63 \\
Minnesota & 30.55 & 38.75 & 36.73 & 84.59 & 190.62 \\
Wisconsin & 36.22 & 15.36 & 36.98 & 158.68 & 247.24 \\
\hline Total & $\mathbf{1 4 2 . 5 2}$ & $\mathbf{1 3 0 . 0 2}$ & $\mathbf{7 9 . 2 3}$ & $\mathbf{4 7 9 . 7 1}$ & $\mathbf{8 3 1 . 4 9}$ \\
\hline \multicolumn{7}{c}{ Residue } \\
\hline Michigan & 18.03 & 18.78 & 1.40 & 60.38 & 98.58 \\
Minnesota & 7.46 & 9.61 & 9.73 & 22.41 & 49.21 \\
Wisconsin & 9.26 & 3.84 & 9.83 & 41.00 & 63.93 \\
\hline Total & $\mathbf{3 4 . 7 5}$ & $\mathbf{3 2 . 2 3}$ & $\mathbf{2 0 . 9 6}$ & $\mathbf{1 2 3 . 7 8}$ & $\mathbf{2 1 1 . 7 2}$ \\
\hline
\end{tabular}

1. National ownerships include lands administered by the national forest system, national grasslands or prairies, the US Forest Service, the Bureau of Land Management, the US Fish and Wildlife Service, the Departments of Defense and Energy, and other federal lands, excluding national parks.

2. State ownerships include lands administered by state Departments of Natural Resources, state universities, and other state agencies.

3. Local government ownerships include lands administered by county and municipal governments.

4. Private ownerships include lands administered by corporations, non-governmental conservation or natural resource organizations, unincorporated local partnerships and clubs, Native American lands, and private individuals. 
Table 2. Timberland area $\left(\mathrm{km}^{2}\right)$ in Province 212 by forest type for the respective northern Lake States. Proportion of statewide timberland area in Province 212 for each forest type group is also listed.

\begin{tabular}{|c|c|c|c|c|c|c|}
\hline \multirow{2}{*}{ Forest type group } & \multicolumn{2}{|c|}{ Minnesota } & \multicolumn{2}{|c|}{ Wisconsin } & \multicolumn{2}{|c|}{ Michigan } \\
\hline & Area & Prop'n & Area & Prop'n & Area & Prop'n \\
\hline White/red/jack pine & 7013.91 & $93 \%$ & 3108.86 & $92 \%$ & 3871.53 & $61 \%$ \\
\hline Spruce/fir & 9966.00 & $97 \%$ & 13609.62 & $97 \%$ & 5207.56 & $92 \%$ \\
\hline Oak/pine & 1955.96 & $87 \%$ & 871.81 & $85 \%$ & 1292.24 & $54 \%$ \\
\hline Oak/hickory & 6883.11 & $51 \%$ & 3781.27 & $46 \%$ & 5923.82 & $35 \%$ \\
\hline Elm/ash/cottonwood & 4201.24 & $51 \%$ & 4225.86 & $68 \%$ & 4519.70 & $64 \%$ \\
\hline Maple/beech/birch & 21358.20 & $92 \%$ & 4305.10 & $76 \%$ & 13053.98 & $86 \%$ \\
\hline Aspen / birch & 11339.78 & $95 \%$ & 22059.98 & $90 \%$ & 10819.96 & $87 \%$ \\
\hline Total & 62718.20 & $81 \%$ & 51962.50 & $83 \%$ & 44688.80 & $68 \%$ \\
\hline
\end{tabular}

White pine = Pinus strobus, Red pine = Pinus resinosa, Jack pine = Pinus banksiana, White spruce = Picea glauca, Black spruce = Picea mariana, Fir = Abies balsamea, Oak = Quercus spp., Hickory = Carya spp., Elm = Ulmus spp., Ash = Fraxinus spp., Cottonwood $=$ Populus deltoides, Sugar maple = Acer saccharum, Beech = Fagus grandifolia, Birch = Betula spp., Aspen $=$ Populus tremuloides, Populus grandidenta 
Table 3. Comparison of total dry roundwood volume estimates (Mt) provided by the 5-year Forest Inventory and Analysis (FIA) inventory cycle ending in 2011 and by the yield equations [31] used in the Forest Age-Class Change Simulator (FACCS) tool. 95\% Confidence Intervals (CI) for FIA and FACCSbased estimates were also used in the validation procedure.

\begin{tabular}{|c|c|c|c|c|c|c|c|}
\hline \multirow{2}{*}{ State } & \multirow{2}{*}{ Forest type } & \multicolumn{2}{|c|}{ FIA - 2011} & \multicolumn{2}{|c|}{ FACCS* - 2011} & \multirow[b]{2}{*}{$\begin{array}{l}\text { Adjustment } \\
\text { Factor }\end{array}$} & \multirow{2}{*}{$\begin{array}{c}\text { FACCS } \\
\text { final } \\
\text { estimate } \\
\text { (Mt) }\end{array}$} \\
\hline & & $\begin{array}{c}\text { Estimate } \\
\text { (Mt) }\end{array}$ & $\begin{array}{l}\mathrm{FIA-Cl} \\
( \pm \mathrm{Mt})\end{array}$ & $\begin{array}{c}\text { Estimate } \\
\text { (Mt) }\end{array}$ & $\begin{array}{c}\text { FACCS-Cl } \\
( \pm \mathrm{Mt})\end{array}$ & & \\
\hline \multirow{7}{*}{ 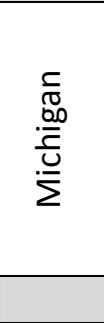 } & White/red/jack pine & 42.19 & 4.23 & 38.40 & 5.73 & 1.10 & 42.19 \\
\hline & Spruce/fir & 43.59 & 3.84 & 23.15 & 2.22 & 1.88 & 43.59 \\
\hline & Oak/hickory & 57.50 & 6.18 & 48.12 & 15.10 & 1.20 & 57.50 \\
\hline & Elm/ash/cottonwood & 22.61 & 3.27 & 14.21 & 1.96 & 1.59 & 22.61 \\
\hline & Maple/beech/birch & 152.96 & 7.91 & 125.67 & 17.31 & 1.22 & 152.96 \\
\hline & Aspen/birch & 45.60 & 4.23 & 36.98 & 3.21 & 1.23 & 45.60 \\
\hline & Total & 364.43 & 8.57 & 286.53 & 35.04 & 1.27 & 364.43 \\
\hline \multirow{7}{*}{ 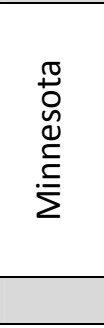 } & White/red/jack pine & 18.79 & 2.49 & 16.59 & 2.48 & 1.13 & 18.79 \\
\hline & Spruce/fir & 34.82 & 2.50 & 33.01 & 3.16 & 1.05 & 34.82 \\
\hline & Oak/hickory & 29.13 & 3.31 & 25.78 & 8.09 & 1.13 & 29.13 \\
\hline & Elm/ash/cottonwood & 17.16 & 2.06 & 16.40 & 2.26 & 1.05 & 17.16 \\
\hline & Maple/beech/birch & 23.19 & 2.88 & 24.43 & 3.36 & 0.95 & 23.19 \\
\hline & Aspen/birch & 68.86 & 3.64 & 67.14 & 5.83 & 1.03 & 68.86 \\
\hline & Total & 191.95 & 5.46 & 183.35 & 22.42 & 1.05 & 191.95 \\
\hline \multirow{7}{*}{ 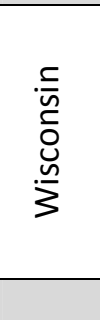 } & White/red/jack pine & 27.17 & 3.27 & 21.00 & 3.13 & 1.29 & 27.17 \\
\hline & Spruce/fir & 17.07 & 2.16 & 12.22 & 1.17 & 1.40 & 17.09 \\
\hline & Oak/hickory & 50.22 & 5.77 & 40.72 & 12.78 & 1.23 & 50.34 \\
\hline & Elm/ash/cottonwood & 19.67 & 2.27 & 15.05 & 2.08 & 1.31 & 19.67 \\
\hline & Maple/beech/birch & 96.24 & 5.43 & 84.89 & 11.69 & 1.13 & 96.24 \\
\hline & Aspen/birch & 37.03 & 2.79 & 31.15 & 2.71 & 1.19 & 37.11 \\
\hline & Total & 247.40 & 6.17 & 205.03 & 25.08 & 1.21 & 247.63 \\
\hline
\end{tabular}

* Initial FACCS estimates were calculated using Domke et al. (2012) yield equations [31]. Adjustment factors (e.g. constants used to scale yield equations to differences in average site quality) were used to modify these local yield equations for use in different states throughout the greater Province 212. 
Table 4. Annual dry roundwood and residue harvest estimates $\left(\mathrm{Mt}^{-1}\right)$ for Province 212 of Michigan, Minnesota, and Wisconsin representing different scenarios used as parameters for modeling probability of future biomass availability.

\begin{tabular}{lcccc}
\hline \multicolumn{5}{c}{ Roundwood $\left(\mathrm{Mt} \mathrm{y}^{-1}\right)$} \\
\hline State & $\begin{array}{c}\text { Minimum } \\
\text { Scenario }\end{array}$ & $\begin{array}{c}\text { Flat } \\
\text { Scenario }\end{array}$ & $\begin{array}{c}\text { Increasing } \\
\text { Scenario }\end{array}$ & $\begin{array}{c}\text { Maximum } \\
\text { Scenario }\end{array}$ \\
\hline Michigan & 3.28 & 3.97 & 4.92 & 6.63 \\
Minnesota & 2.06 & 2.49 & 3.08 & 4.26 \\
Wisconsin & 2.46 & 3.00 & 3.69 & 4.82 \\
\hline Total & $\mathbf{7 . 8 0}$ & $\mathbf{9 . 4 6}$ & $\mathbf{1 1 . 6 9}$ & $\mathbf{1 5 . 7 1}$ \\
\hline Michigan & 0.52 & Residues $65 \%\left(\mathrm{Mt} \mathrm{y}^{-1}\right)$ & & 1.06 \\
Minnesota & 0.37 & 0.63 & 0.78 & 0.76 \\
Wisconsin & 0.39 & 0.44 & 0.55 & 0.80 \\
\hline Total & $\mathbf{1 . 2 8}$ & 0.48 & 0.59 & $\mathbf{2 . 6 2}$ \\
\hline
\end{tabular}

Minimum scenario reflects the lowest harvest value arising from the MM-DHT (Minnesota Declining Harvest Trend), Flat scenario values are the average of the Exponential Smoothing and Damped Trend (ESDT) harvest values from 2010-2110; Increasing scenario values are the averages of the respective States' increasing harvest trend; Maximum scenario reflects the long term sustained yield values for the respective states provided by FACCS model. See Figure 2 for harvest trend scenarios. 
Table 5. Simulation results showing predicted mean annual dry roundwood harvest and residue collection $\left(\mathrm{Mt}^{-1}\right)$ and associated 95\% confidence intervals assuming 65\% collection in the Lake States' Province 212.

\begin{tabular}{lcccc}
\hline \multicolumn{5}{c}{ Roundwood $\left(\mathrm{Mt} \mathrm{y}^{-1}\right)$} \\
\hline State & Mean & $\boldsymbol{\sigma}$ & $\mathbf{2 . 5 0 \%}$ & $\mathbf{9 7 . 5 0 \%}$ \\
\hline Michigan & 4.75 & 0.73 & 3.55 & 6.20 \\
Minnesota & 3.01 & 0.48 & 2.24 & 3.97 \\
Wisconsin & 3.52 & 0.51 & 2.66 & 4.52 \\
\hline Total & $\mathbf{1 1 . 2 7}$ & $\mathbf{1 . 7 1}$ & $\mathbf{8 . 4 5}$ & $\mathbf{1 4 . 7 0}$ \\
\hline \multicolumn{5}{c}{ Residues } \\
\hline \multicolumn{5}{c}{ 65\% $\left(\mathrm{Mt} \mathrm{y}^{-1}\right)$} \\
\hline Michigan & 0.12 & 0.56 & \\
Minnesota & 0.76 & 0.09 & 0.40 & 0.99 \\
Wisconsin & 0.54 & 0.09 & 0.43 & 0.75 \\
\hline Total & 0.57 & $\mathbf{0 . 2 9}$ & $\mathbf{1 . 3 9}$ & $\mathbf{2 . 4 5}$ \\
\hline
\end{tabular}


Table 6. Annual availability of dry residues $\left(\mathrm{Mt}^{-1}\right)$ at $65 \%$ collection rate in the Lake States under different ownership types and three harvest scenarios. See Table 4 for description of harvest scenarios.

\begin{tabular}{clccccc}
\hline Harvest & States & National & State & Local & Private & All lands \\
\hline \multirow{3}{*}{ Minimum } & Michigan & 0.07 & 0.12 & 0.10 & 0.22 & 0.52 \\
& Minnesota & 0.06 & 0.09 & 0.00 & 0.21 & 0.37 \\
& Wisconsin & 0.05 & 0.03 & 0.07 & 0.25 & 0.39 \\
\hline \multirow{3}{*}{ Average } & Total & $\mathbf{0 . 1 8}$ & $\mathbf{0 . 2 4}$ & $\mathbf{0 . 1 7}$ & $\mathbf{0 . 6 8}$ & $\mathbf{1 . 2 8}$ \\
& Michigan & 0.11 & 0.18 & 0.15 & 0.32 & 0.76 \\
& Minnesota & 0.09 & 0.13 & 0.01 & 0.31 & 0.54 \\
& Wisconsin & 0.07 & 0.04 & 0.10 & 0.37 & 0.57 \\
\hline \multirow{3}{*}{ Maximum } & Total & $\mathbf{0 . 2 6}$ & $\mathbf{0 . 3 5}$ & $\mathbf{0 . 2 5}$ & $\mathbf{1 . 0 0}$ & $\mathbf{1 . 8 7}$ \\
& Michigan & 0.15 & 0.25 & 0.21 & 0.45 & 1.06 \\
& Minnesota & 0.13 & 0.19 & 0.01 & 0.44 & 0.76 \\
& Wisconsin & 0.09 & 0.06 & 0.14 & 0.51 & 0.80 \\
\hline & Total & $\mathbf{0 . 3 7}$ & $\mathbf{0 . 5 0}$ & $\mathbf{0 . 3 5}$ & $\mathbf{1 . 4 0}$ & $\mathbf{2 . 6 2}$ \\
\hline
\end{tabular}


Table 7. Comparison of dry roundwood harvest projection results (Mt) for Province 212 region of Minnesota with other studies.

\begin{tabular}{llcl}
\hline Harvest & Study & $\begin{array}{c}\text { Roundwood* } \\
\text { (Mt) }\end{array}$ & Scenario \\
\hline \multirow{3}{*}{ Average } & GEIS, 1994 [25] & 3.70 & 'Base' scenario (Table 5.4) \\
& Schwalm, 2009 [26] & 2.77 & 'Baseline' scenario, annualized for 50 y planning horizon \\
& This study (Avg.) & 3.01 & Average predicted harvest (2010-2110) \\
\hline \multirow{3}{*}{ Maximum } & GEIS, 1994 & 5.42 & 'High' Scenario (Table 7.4) \\
& Schwalm, 2009 & 3.76 & 'No even flow' scenario maximum possible harvest \\
& This study (Max.) & 4.26 & FACCS projected long-term sustained yield (2010-2110) \\
\hline
\end{tabular}

* The results from other studies were converted into Province 212 estimates by multiplying statewide results with proportion of statewide area within Province 212 (83\%). 
Table 8. Power generation potential and net GHG reduction potential of forest derived residues (oven dry) in the northern Lake State under different harvest scenarios projected over the 100 -year study period.

\begin{tabular}{|c|c|c|c|c|c|c|c|c|c|c|c|}
\hline \multirow{2}{*}{$\begin{array}{l}\text { Harvest } \\
\text { scenario }\end{array}$} & \multirow{2}{*}{ States } & \multirow{2}{*}{$\begin{array}{l}\text { Residues } \\
\text { (Oven dry) } \\
\text { available } \\
\text { (Mt) }\end{array}$} & \multirow{2}{*}{$\begin{array}{l}\text { Residue } \\
\text { (Oven dry) } \\
\text { removed } \\
\text { (Mt) }\end{array}$} & \multirow{2}{*}{$\begin{array}{c}\text { Power* } \\
\text { generation } \\
\text { potential } \\
\text { (GW·h) }\end{array}$} & \multirow{2}{*}{$\begin{array}{l}\text { Reduced }^{\$} \\
\text { emissions } \\
\left(\mathrm{Mt} \mathrm{CO}_{2} \mathrm{e}\right)\end{array}$} & \multicolumn{3}{|c|}{$\begin{array}{c}\text { Avoided emissions }{ }^{\#} \\
\left(\mathrm{Mt} \mathrm{CO}_{2} \mathrm{e}\right)\end{array}$} & \multicolumn{3}{|c|}{$\begin{array}{l}\text { Net emission reduction potential } \\
\qquad\left(\mathrm{Mt} \mathrm{CO}_{2} \mathrm{e}\right)\end{array}$} \\
\hline & & & & & & $\begin{array}{c}100 \% \\
\text { Aerobic }\end{array}$ & $\begin{array}{c}90 \% \\
\text { Aerobic }\end{array}$ & $\begin{array}{c}50 \% \\
\text { Aerobic }\end{array}$ & $\begin{array}{c}100 \% \\
\text { Aerobic }\end{array}$ & $\begin{array}{c}90 \% \\
\text { Aerobic } \\
\end{array}$ & $\begin{array}{c}50 \% \\
\text { Aerobic } \\
\end{array}$ \\
\hline & Michigan & 80.07 & 52.04 & 59.33 & 53.33 & 82.56 & 108.36 & 133.34 & 135.89 & 161.69 & 186.67 \\
\hline \multirow[t]{4}{*}{ Minimum } & Minnesota & 56.34 & 36.62 & 41.75 & 37.52 & 59.48 & 78.06 & 96.06 & 97.00 & 115.59 & 133.59 \\
\hline & Wisconsin & 60.63 & 39.41 & 44.85 & 40.32 & 62.54 & 82.08 & 101.01 & 102.86 & 122.40 & 141.32 \\
\hline & Total & 197.03 & 128.07 & 145.93 & 131.17 & 204.58 & 268.50 & 330.41 & 335.76 & 399.68 & 461.58 \\
\hline & Michigan & 116.59 & 75.78 & 86.39 & 77.66 & 120.22 & 157.79 & 194.17 & 197.88 & 235.44 & 271.82 \\
\hline \multirow[t]{4}{*}{ Average } & Minnesota & 82.76 & 53.79 & 61.32 & 55.12 & 87.37 & 114.67 & 141.11 & 142.49 & 169.79 & 196.23 \\
\hline & Wisconsin & 87.95 & 57.17 & 65.06 & 58.48 & 90.72 & 119.07 & 146.52 & 149.20 & 177.55 & 205.00 \\
\hline & Total & 287.30 & 186.74 & 212.78 & 191.26 & 298.32 & 391.52 & 481.80 & 489.58 & 582.79 & 673.06 \\
\hline & Michigan & 163.84 & 106.50 & 121.41 & 109.13 & 168.95 & 221.74 & 272.86 & 278.08 & 330.87 & 381.99 \\
\hline \multirow[t]{3}{*}{ Maximum } & Minnesota & 117.47 & 76.36 & 87.05 & 78.24 & 124.02 & 162.77 & 200.30 & 202.27 & 241.02 & 278.55 \\
\hline & Wisconsin & 122.52 & 79.64 & 90.63 & 81.47 & 126.38 & 165.87 & 204.11 & 207.85 & 247.34 & 285.58 \\
\hline & Total & 403.83 & 262.49 & 299.09 & 268.85 & 419.35 & 550.37 & 677.27 & 688.20 & 819.22 & 946.12 \\
\hline
\end{tabular}

*Assuming energy content of wood (HHV) $19 \mathrm{MJ} \mathrm{kg}^{-1}, 36 \%$ conversion efficiency, and 60\% plant capacity [42, 44].

\$Assuming replacement of coal in Average, NSPS, LEBS coal-based technology power plants [42].

${ }^{\#}$ The GHG $\left(\mathrm{CO}_{2} \mathrm{e}\right)$ emissions for $100 \%, 90 \%$ and $50 \%$ aerobic decays were taken as $1.85,2.43$ and $2.99 \mathrm{~kg} \mathrm{~kg}^{-1}$ wood decayed respectively. 
Figure 1. Ecological Province 212 of the northern Lake States, USA with major forest types depicted. Forest type classification is based on GAP data.

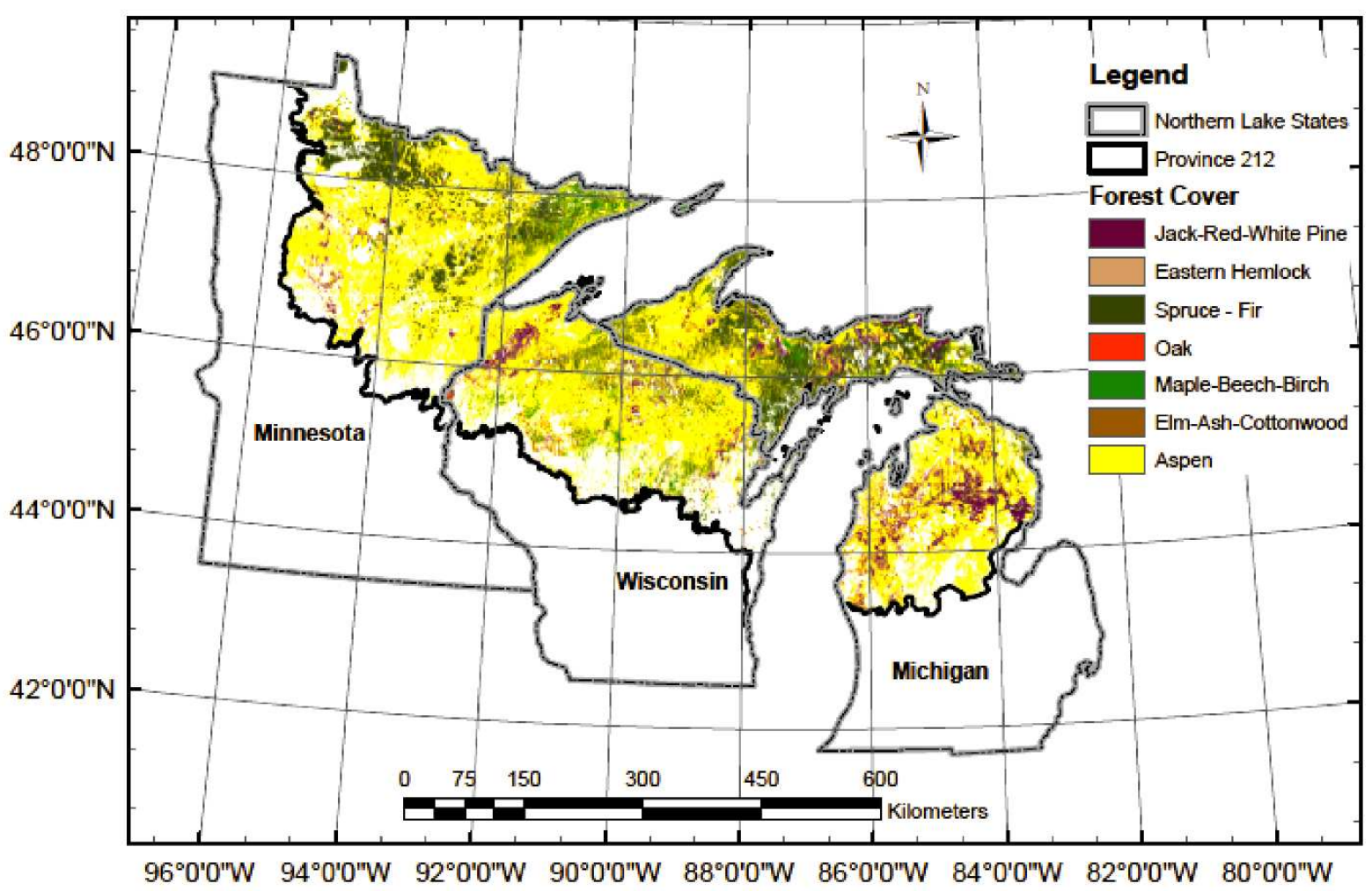


Figure 2: Flow Chart showing the sources and process involved in the study.

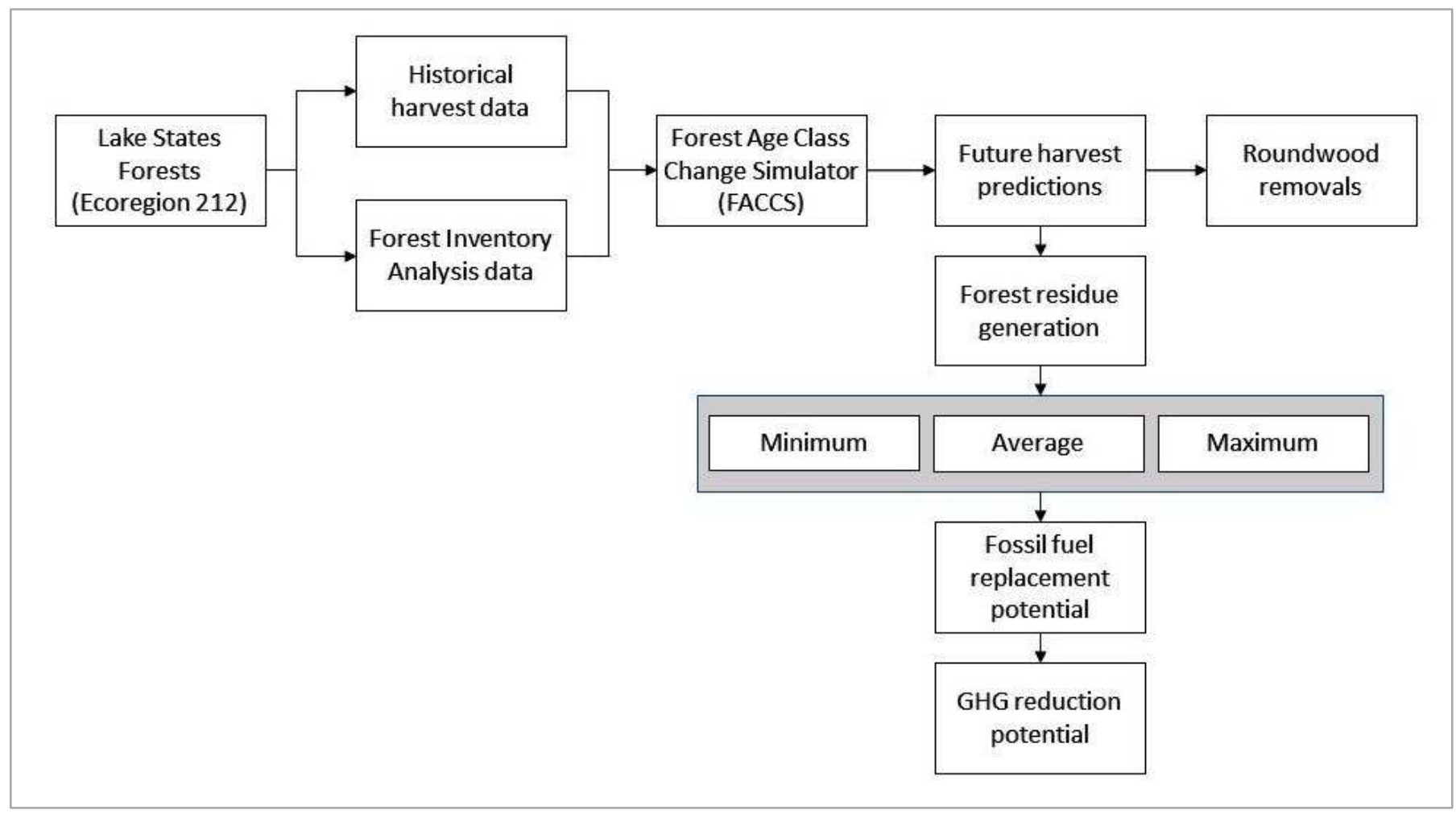


Figure 3. Graph showing different harvest trends developed from historical data for creating a probability distribution describing likely future harvests in Minnesota.

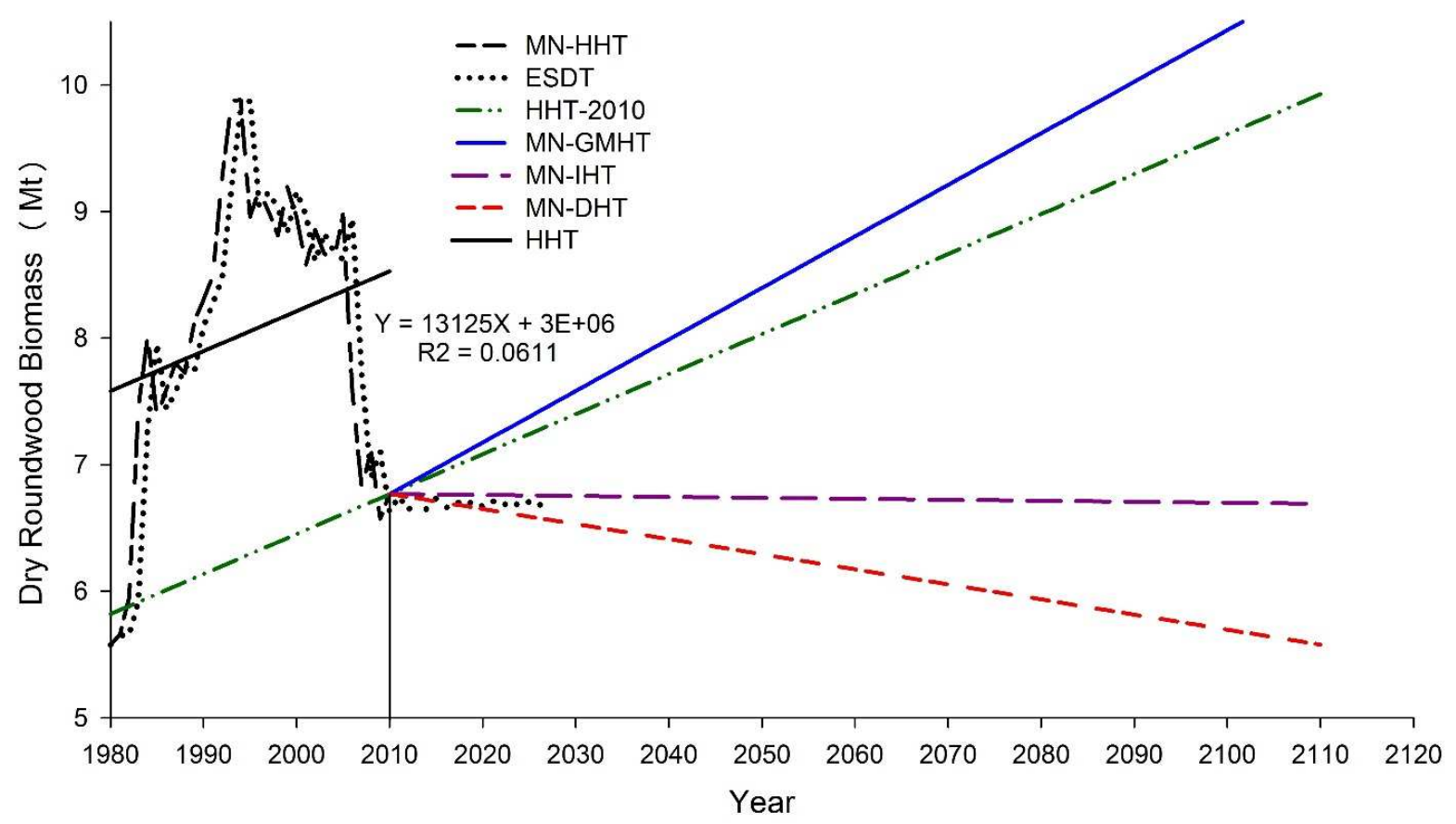

$\mathrm{HH}=$ Historical harvests; HH-ESDT = Historical harvests processed by exponential smoothing with damped trend; MN-HHT= Minnesota historical harvest trend through 2010; MN-GMHT= Minnesota growth to maximum harvest trend; MN-ESDT= Minnesota exponential smoothing with damped trend; MN-DHT = Minnesota declining harvest trend; HHT= Historical harvest trendline. 
Figure 4. Probability distribution results for Dry Roundwood (t), Minnesota $2011-2110$.
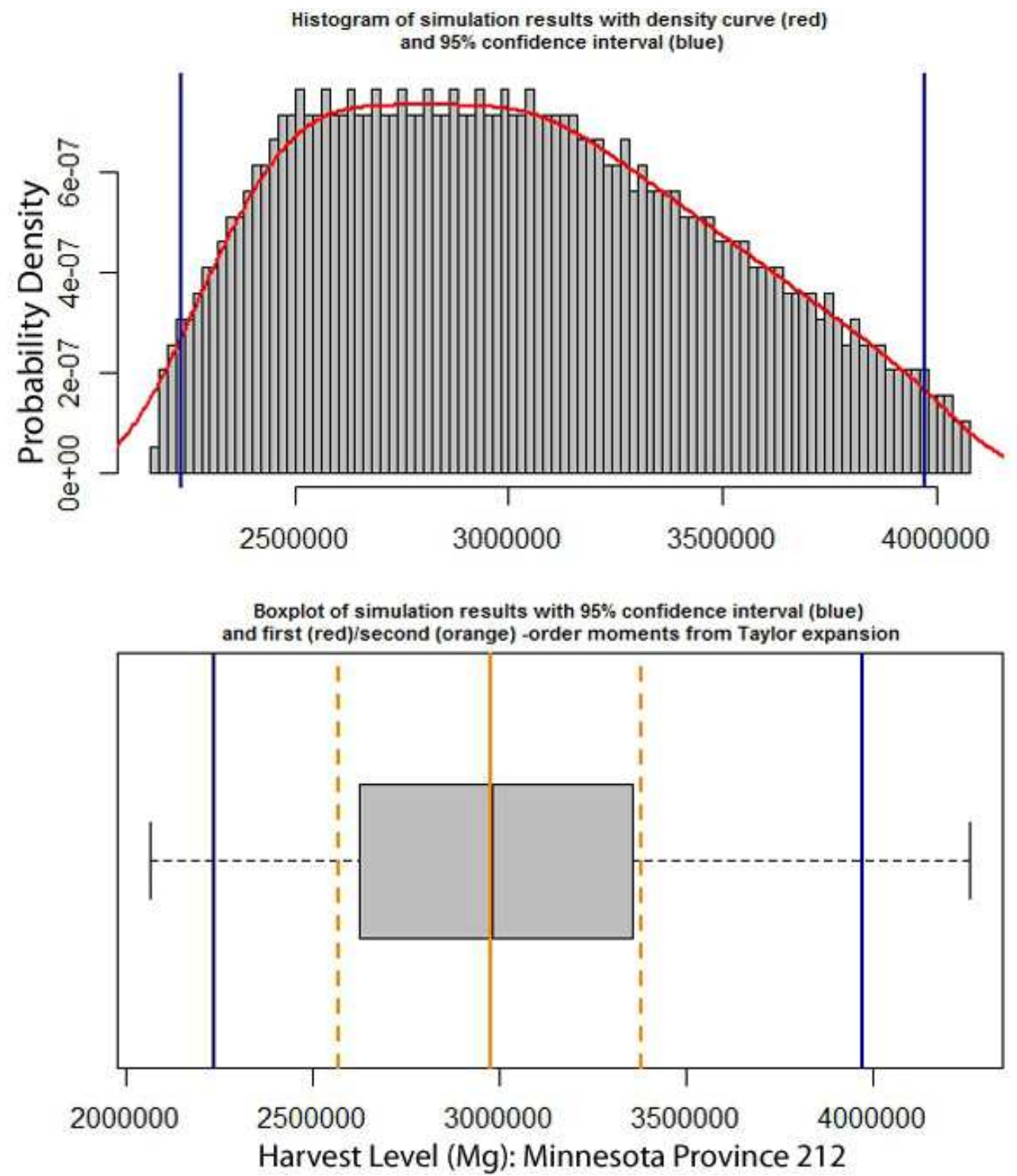
Figure 5. Projected probability distribution for dry harvest residue production ( $\mathrm{t}$ ) in Minnesota from 2011 $-2110$.
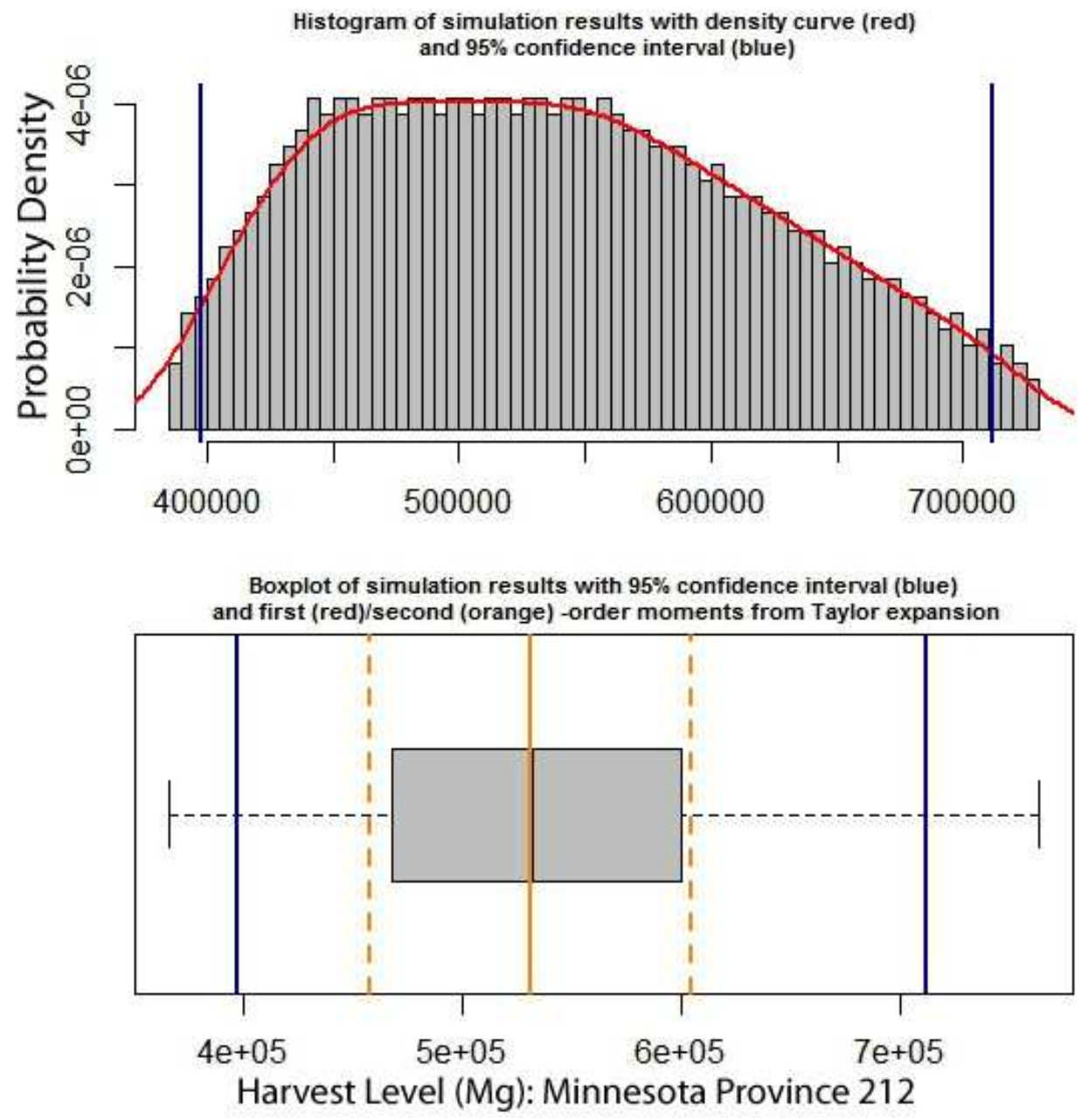
Figure 6. Projected dry residue (Mt) availability in Province 212 of MN compared with results from other studies [11, 20, 25, 26]. GEIS (1994) 4.9 million cord scenario; Schwalm (2009) (a) Baseline scenario; Schwalm (2009) (b) 5.5 Million cord scenario. All values from other studies were proportionally converted into Province 212 estimates assuming a 65\% collection rate for comparison.

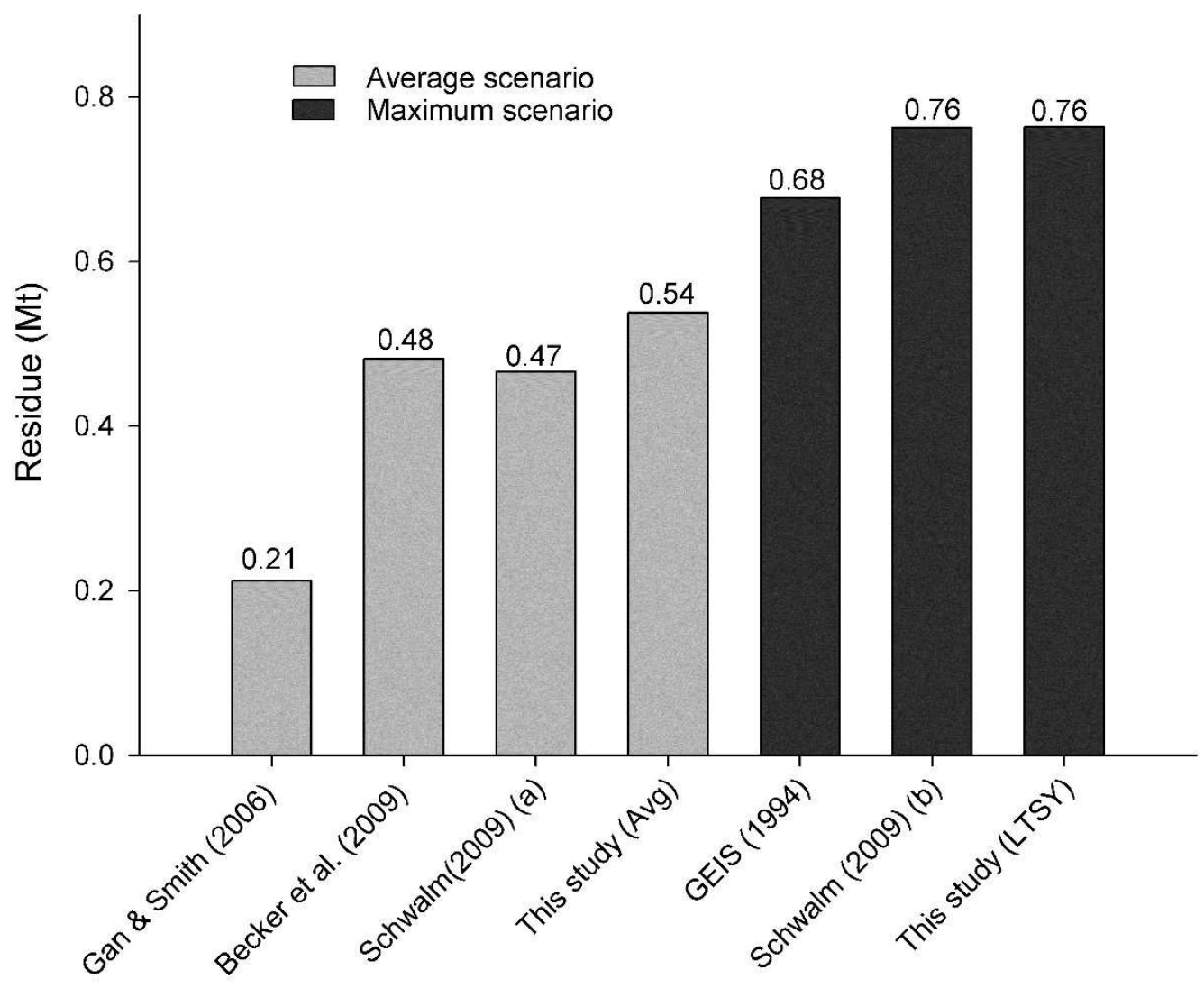

